\title{
12. Sorry, but the Indigenous affairs revolution continues
}

\author{
WILL SANDERS AND JANET HUNT
}

\section{Introduction}

In Indigenous affairs, the Rudd Labor government was bequeathed three major legacies from the 11-and-a-half-year reign of the Howard Coalition government. The first, dating from the recommendations of the 1997 Bringing Them Home report of the Human Rights and Equal Opportunity Commission, was John Howard's refusal to apologise for policies up to 1970 that had led to large-scale separation of Aboriginal children from their families and communities on the basis of race. The second, dating from 2004 and early 2005, was the abolition of the Aboriginal and Torres Strait Islander Commission (ATSIC), a national statutory authority and representative body for Indigenous Australians. The third, dating from 2007, was the Howard government's intervention in the Northern Territory, the so-called Northern Territory Emergency Response (NTER), in the wake of a major Aboriginal child protection report. During its two and half years, the Rudd government attempted to address each of these three major legacies, though in different time scales and in very different ways. First, quite quickly and with great fanfare, the Rudd government said 'sorry' to the Stolen Generations. Somewhat more slowly, it reviewed then extended the NTER. More slowly still, the Rudd government moved to re-establish a national representative body for Indigenous Australians. We will examine each of these developments in turn and suggest how they have contributed to the Rudd government's approach to Indigenous affairs. We will also note two other developments in Indigenous affairs during the Rudd years: belated support for the UN Declaration on the Rights of Indigenous Peoples and developments in multilateral intergovernmental agreement making.

Analytically, our chapter is built on the idea of generational revolutions in Australian Indigenous affairs (Sanders 2008). This suggests that, as a difficult cross-cultural policy arena and the moral cause célèbre of Australian nationhood, Indigenous affairs goes through generational cycles. Approaches to Indigenous affairs that are pursued confidently at one point in time become seen, after 30 or 
40 years, as having failed to live up to expectations. Established approaches are then abandoned in favour of some newly labelled and conceived approach. Such a generational revolution occurred in the late 1960s and early 1970s, when the key term of Indigenous affairs changed from assimilation to self-determination and the Commonwealth changed from having a regional role in the Northern Territory to having a national role in Indigenous affairs. Another generational revolution appears to have occurred in the early 2000s, with the diagnosed failure and abandonment of both self-determination and ATSIC. Since then the new language and institutional arrangements of Indigenous affairs have emphasised ideas such as responsibility sharing, partnership and a whole-of-government approach. These ideas are not actually as new as claimed, but this is of little moment. They are new enough to disparage what has gone before as a failure and to launch a raft of reforms. Our argument is that the Rudd government has gone along with and continued this generational revolution in Indigenous affairs that developed in the late Howard years. This will be evident in the way in which we write about some of the events of the Rudd years in Indigenous affairs, such as the continuing dominant language of past policy failure. We will return, in our concluding analysis, to the idea of generational revolutions and to one other general aspect of the Rudd government's approach to Indigenous affairs: its emphasis on evidence.

\section{'Sorry' and 'closing the gap'}

As Leader of the Opposition, Rudd made clear that, unlike Howard, he was willing to respond to the 1997 Bringing Them Home report by sponsoring a governmental and parliamentary apology to the Stolen Generations. Once elected, discussion turned to the timing of the apology and what it would involve. During January 2008, it was decided that the apology would be the first item of business for the new Parliament on 13 February (following the formal opening of Parliament, which would for the first time include an Indigenous welcome to country). Rudd also made clear that the apology would not involve direct monetary compensation for individual members of the Stolen Generations, as had also been recommended by the Bringing Them Home report and had recently been implemented in a Tasmanian government scheme (Grattan and Wright 2008; Lennon 2008). Despite this restriction, which caused some adverse comment from Indigenous leaders and others, the apology was both presented and received as a major change in public policy, which clearly and immediately differentiated the Rudd government from its predecessor.

Rudd's address to the Parliament supporting the motion of apology contained some powerful rhetoric. He spoke of nations needing to 'become fully reconciled to their past' in order to 'go forward with confidence', of Australia needing to 
'remove a great stain from the nation's soul and, in a sprit of true reconciliation, to open a new chapter' (Parliament of Australia 2008). He recounted the story of one old Aboriginal woman who had been taken from her family near Tennant Creek in 1932 at the age of four. He spoke of this being just 'one story' among 'thousands' that 'cry out to be heard...cry out for an apology', and of 'universal human decency' demanding that the nation 'right an historical wrong'. He spoke of 'our parliaments' being 'ultimately responsible' for enacting laws that 'made the stolen generations possible' and of them needing to bear the 'burdens' of past laws as well as the 'blessings' (Parliament of Australia 2008). The climax of this powerful rhetoric seemed to come in a series of short, simple sentences:

It is time to reconcile. It is time to recognise the injustices of the past. It is time to say sorry. It is time to move forward together. To the stolen generations, I say the following: as Prime Minister of Australia, I am sorry. On behalf of the government of Australia, I am sorry. On behalf of the Parliament of Australia, I am sorry. I offer you this apology without qualification. (Parliament of Australia 2008)

Rudd went on to propose that if the apology is 'accepted in the spirit of reconciliation in which it is offered', there could 'today' be 'a new beginning for Australia' (Parliament of Australia 2008).

In the final third of his address to Parliament, Rudd moved to a somewhat different tone and focus. He spoke of Australians being 'practical' as well as 'passionate' and of the importance of 'substance' as well as 'symbolism'. He spoke of 'our challenge for the future' being to build a 'bridge based on a real respect' and 'a new partnership between Indigenous and non-Indigenous Australians'. A 'part of that partnership', he noted, would be 'expanded Link-up and other critical services to help the stolen generations to trace their families if at all possible and to provide dignity in their lives' (Parliament of Australia 2008).

The 'core of this partnership', he argued, would, however, be 'closing the gap between Indigenous and non-Indigenous Australians on life expectancy, educational achievement and employment opportunities'. He argued that 'old approaches' to these issues were 'not working' and that the new partnership would allow 'flexible, tailored, local approaches to achieve commonly-agreed national objectives'. He resolved to 'begin with the little children - a fitting place to start on this day of apology for the stolen generations'. Within five years, he aimed to have 'every Indigenous four-year old in a remote Aboriginal community enrolled in and attending a proper early childhood education centre' (Parliament of Australia 2008).

This would, Rudd argued, 'be hard', but not 'impossible'. Achieving it depended on 'clear goals, clear thinking, and placing an absolute premium on respect, cooperation and mutual responsibility as the guiding principles of this new partnership on closing the gap' (Parliament of Australia 2008). 
The 'mood of the nation', Rudd argued, was 'calling on' politicians to move beyond 'infantile bickering... point scoring and... mindlessly partisan politics' to 'elevate this one core area of national responsibility to a rare position beyond the partisan divide' (Parliament of Australia 2008). He then proposed a 'joint policy commission' led by himself and the Leader of the Opposition, which would begin by developing 'an effective housing strategy for remote communities over the next five years' before then possibly turning its attention to 'the task of constitutional recognition of the first Australians'. All this, he said, was 'consistent with the longstanding platform commitments of my party', the 'preelection position of the opposition' and 'the government's policy framework, a new partnership for closing the gap' (Parliament of Australia 2008).

Some of this rhetoric in the last third of Rudd's address was reminiscent of the Howard government, which had also emphasised the 'practical' over the 'symbolic' and the pursuit of equality of outcomes in areas such as education, employment and housing (Sanders 2005). Another element of continuity was the emphasis on past policy failure and the consequent call for significantly changed policy and institutional approaches. Rudd's Minister for Families, Housing, Community Services and Indigenous Affairs, Jenny Macklin, continued this emphasis in an address to the National Press Club in late February 2008. She began by focusing on a West Australian coroner's report into 22 recent Aboriginal deaths in the Kimberley. The coroner, she said: 'paints a picture of a failed community... where...there isn't just a gap between Aboriginal and nonAboriginal Australians - there is a vast and worsening gulf' (Macklin 2008a).

Macklin used these findings of failure to announce a trial income-management scheme for welfare recipients in 'selected Western Australian communities'. This would 'use existing legislative authority' and 'be part of the national child protection framework'. It would also, Macklin noted, draw in the WA government through requirements for 'appropriate services' and 'an expansion of alcohol restrictions' (Macklin 2008a). What was 'at stake', Macklin argued, was 'a generation of Indigenous children...for whom time is fast running out'. 'Decades of failure', she argued, had 'spawned... another country...the unluckiest of countries... within our borders' (Macklin 2008a). Macklin insisted on finding 'new ways of doing things because the old ways have so comprehensively failed' and on working 'with Indigenous people in a partnership built on respect and mutual responsibility'. All her decisions, she argued, would be guided 'by one single criterion-evidence', which was her 'abiding fixation' (Macklin 2008a).

Macklin went on to talk about 'decent housing' as an 'essential foundation to bridging the gulf' and of how the government would act to overcome 'extreme overcrowding' in Indigenous housing both by promoting home ownership and by building more public housing in remote areas using a 'strategic alliance' approach (Macklin 2008a). The advantages of this approach, she argued, 
included the 'involvement of each community in how the work is delivered in that community', a 'greater visibility of the cost of risk', 'innovation in design and...logistical solutions' and 'employment and training of local Indigenous people' (Macklin 2008a). Macklin also spoke about encouraging the states to make changes to their land regimes in discrete Indigenous communities in order to 'secure long term [land] tenure' to 'underpin major housing investment', and of the Commonwealth already doing this in the Northern Territory (Macklin 2008a). Her commitment was to increasing the range of housing options or choices available to Indigenous people, particularly those in remote areas. This would take 'years of hard work' and 'determination', but she declared herself 'ready' for this as both a 'realist' and an 'optimist' (Macklin 2008a).

One of us responded to this address by arguing that the focus on past policy failure and a change to new ideas in Indigenous affairs was becoming overdone. It was time to start focusing and building on the strengths and successes of established organisations and approaches, even if limited. It was also noted that new ideas would, by their nature, not have evidence to support them (Hunt 2008). Macklin's rhetoric suggested just how much the Rudd government was going along with the generational revolution in Indigenous affairs established in the late Howard years. Ideas of failure and change were still dominating and so too, through the 'closing the gap' label, were ideas of pursuing socioeconomic equality rather than valuing Indigenous diversity or difference (Altman 2009).

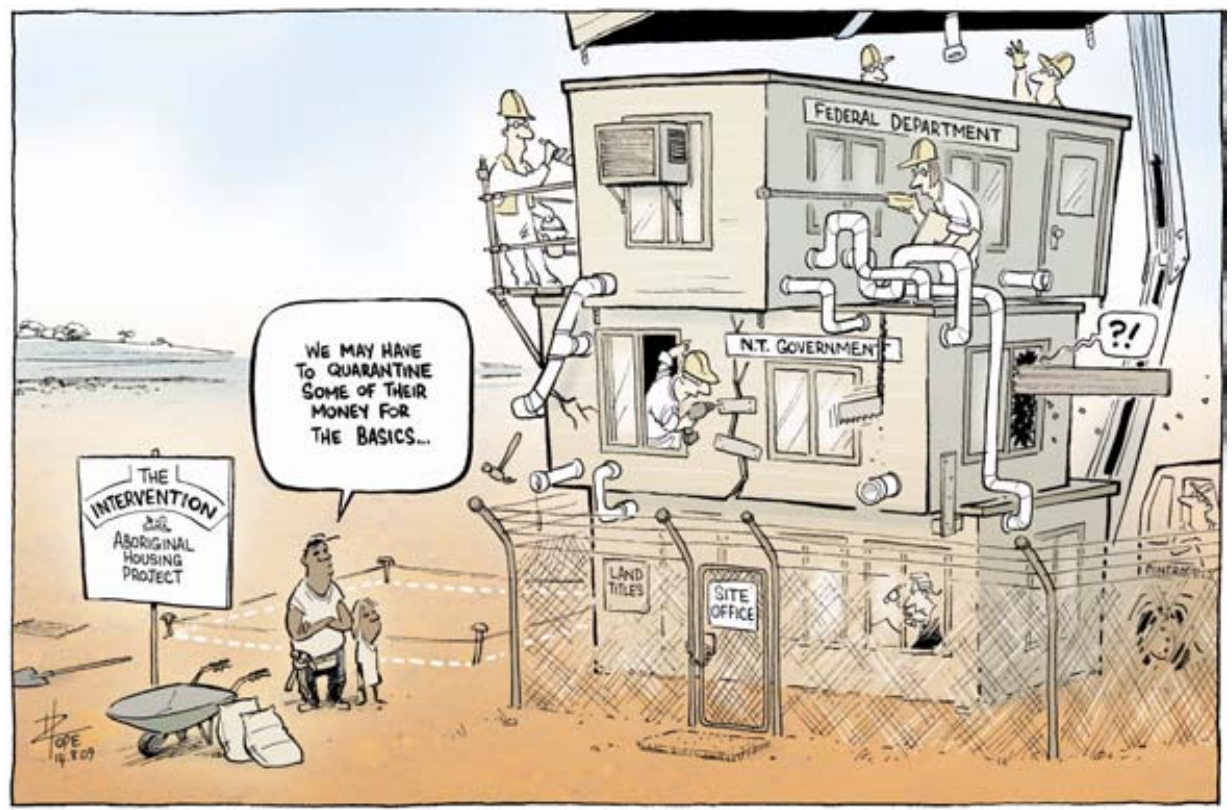

Source: David Pope, The Canberra Times, 14 August 2009 
The Rudd Government

\section{Extending the NTER}

Unlike the differentiation over the apology to the Stolen Generations, the Rudd opposition's response to the Howard government's launching of the NTER on 21 June 2007 was primarily one of support. Rudd committed, if he won government, to reviewing the NTER after one year's operation, though there were two elements of it that he promised to halt before this review: the abolition of an Indigenous-specific workfare scheme called Community Development Employment Projects (CDEP) and the abolition of permits for access to Aboriginal land in the Northern Territory. ${ }^{1}$ In office, Rudd remained true to these commitments. The new government immediately placed a moratorium on further CDEP closures (which by the election had fallen from 8000 to 5000 participants across the Northern Territory), though there was also a commitment to reforming CDEP over coming months. In January 2008, Minister Macklin met with the NTER Taskforce and used the occasion to reiterate the government's support for an 'evidenced-based approach' to the 'excellent job' they were doing in a 'challenging environment' (Macklin 2008 b). During that month, she also signed regulations for the introduction of income management to a number of additional declared areas in the Northern Territory, thereby showing support for what was coming to be seen as the most central measure of the NTER. Then in February, Macklin declined to produce regulations that would have ended the need for permits to travel on roads on Aboriginal land in the Northern Territory and also introduced legislation to reinstate a revised version of the permit system in communities (Macklin 2008c).

In early June 2008, Macklin appointed an independent NTER Review Board comprising three members (two of whom were Indigenous) and an 11-member expert support group. She emphasised again the government's commitment to an 'evidenced-based approach to closing the gap between Indigenous and non-Indigenous Australians', as well as directing the Review Board to make an assessment of the impact of each NTER measure (Macklin 2008d). Later in the month, Macklin expressed the view that the NTER was, after one year, 'making important progress' and that the government was 'determined to keep moving forward' (Macklin 2008e).

The NTER Review Board report, published in October 2008, expressed similar sentiments of progress. The board said it had 'observed definite gains' as a result of the NTER and 'had heard widespread, if qualified, community

1 The CDEP scheme was introduced on a small scale in remote areas by the Fraser Coalition government from 1977, administered by the Department of Aboriginal Affairs. During the late 1980s and early 1990s, it became a large national program, accounting for one-third of the budget of the Department of Aboriginal Affairs, and later ATSIC, and having up to 35000 Indigenous participants. 
support for many NTER measures'. It argued that the 'situation in remote communities and town camps was - and remains - sufficiently acute to be described as a national emergency' and that the NTER 'should continue' (Yu et al. 2008:10). The board also argued, however, that the NTER had 'diminished its own effectiveness through its failure to engage constructively with the Aboriginal people it was intended to help' and that the 'positive potential' of particular NTER measures had been 'dampened and delayed by the manner in which they were imposed' (Yu et al. 2008:9-10). Accordingly, two of the board's three overarching recommendations aimed to improve the way in which the NTER was being pursued. One recommended that the NT and Commonwealth governments 'reset their relationship with Aboriginal people based on genuine consultation, engagement and partnership' and the other that government 'actions affecting Aboriginal communities' be made to 'conform with the Racial Discrimination Act 1975 ' and thereby 'respect Australia's human rights obligations' (Yu et al. 2008:12). ${ }^{2}$

On specific NTER measures, the Review Board noted that income management was 'the most widely recognised measure' and that 'competing views' of its application to more than 13000 Aboriginal people by June 2008 were 'expressed with considerable passion' (Yu et al. 2008:20). The Review Board recommended that 'the blanket application of compulsory income management' in declared areas of the Northern Territory should 'cease', but that compulsory income management based on 'relevant behavioural triggers' should be introduced across the whole Northern Territory for more limited numbers of people, as well as 'voluntary' income management for others who wanted it (Yu et al. 2008:23). Most other specific NTER measures - in areas such as policing, alcohol management, education, families, health, child protection and land-were similarly supported by the board, albeit often with modification.

The Rudd government's response to this independent Review Board report was swift and clear. Compulsory income management would continue as a 'comprehensive' measure applying to large numbers of Aboriginal people in the Northern Territory because of its 'demonstrated benefits for women and children' (Macklin 2008f:1). The government accepted the three overarching recommendations of the report and would, as a consequence, work towards 'greater emphasis on community development and engagement' in the NTER, and would over the next year 'design a compulsory income management policy' that was not built on the suspension of the Racial Discrimination Act. But the government was 'not prepared to disrupt current beneficial measures or place them at risk of legal challenge', so in the short-term comprehensive,

2 The original NTER legislation, passed in August 2007, had suspended the application of the Racial Discrimination Act to its various measures. 
compulsory income management in declared areas would continue unchanged (Macklin 2008f:3). This response was both an endorsement and a repudiation of the Review Board's work. It made very clear that the Rudd government was committed to supporting and extending the NTER, not only in the largescale application of the key income-management measure, but more generally as well.

The Rudd government then took more than a year to develop a policy statement about how it would reinstate the Racial Discrimination Act while continuing to pursue large-scale, compulsory income management and other measures within the NTER (Australian Government 2009a; Macklin 2009a). Along the way it passed legislation that brought the Indigenous-specific CDEP workfare scheme closer to the social security system, moving participants from being part-time employees of participating organisations to more clearly being welfare recipients who may be subject to income management. The government also in this period held widespread consultations with Aboriginal people in the Northern Territory, though with the clear intention of maintaining and extending income management and other measures within the NTER (Australian Government 2009b, 2009c). This led to some concerted criticism (Nicholson et al. 2009). At the end of this year-long process, the Rudd government's proposal was to introduce compulsory income management across the whole Northern Territory during the second half of 2010 for about 20000 people divided into four categories: those aged under twenty-five who had been in receipt of an unemployment-related benefit for more than three months, those aged over twenty-five who had been in receipt of an unemployment- related benefit for more than a year, people judged by a social security delegate to be vulnerable to issues such as 'financial crisis, domestic violence or economic abuse' and those referred by child protection authorities (Australian Government 2009a:9). There would also be the option of voluntary income management, with some minor additional payment incentives, for those who wanted it. Evaluation of this proposed new, nondiscriminatory income-management scheme in the Northern Territory during 2011-12, as well as of the trials already under way in Western Australia and Queensland, would then inform the implementation of income management in other areas of 'disadvantage in Australia' (Australian Government 2009a:10).

These proposals for compulsory income management, which would cover large numbers of people across the Northern Territory from late 2010, and also in time extend to other people and areas, provoked considerable public debate during the early months of 2010. The former chief minister of the Northern Territory and now chief executive of the Australian Council of Social Services, Clare Martin, strongly opposed large-scale, compulsory income management and so too did most welfare organisations. A few welfare 
interests were, however, more supportive and once the Coalition opposition had declared its support in late March 2010, the proposed legislation seemed destined to pass. By coincidence, it was on 21 June 2010, the third anniversary of the launching of the NTER, that the Senate finally passed the social security amendment bill that provided for this new scheme of income management not relying on the suspension of the Racial Discrimination Act (Macklin 2010a, 2010b). This extension of a key measure within the NTER would be one of the last legislative acts of the Rudd government, before Julia Gillard became Prime Minister on 24 June.

\section{A new national indigenous representative body}

The abolition of ATSIC in 2004 and 2005 had led to Indigenous-specific programs being reallocated to commonwealth departments and there no longer being a broad-based, national Indigenous representative body. The Howard government's replacement advisory body, the National Indigenous Council, was a small group of government-appointed individuals and, within a month of coming to office, Macklin faced the decision of whether their terms should be extended beyond December 2007. Her decision to disband the National Indigenous Council inevitably led to the issue of what approach to a national Indigenous representative body the Rudd government would now be taking. Macklin spoke of the government undertaking 'discussions with Indigenous people' in an attempt to 'strengthen links' with 'urban, regional and remote Indigenous communities'. The aim would be to have a new national Indigenous representative body in place by the end of the parliamentary term. But whatever the new body might look like, the Rudd government would 'not be establishing a new ATSIC' (Macklin 2008g).

During 2008, it was the Aboriginal and Torres Strait Islander Social Justice Commissioner within the Australian Human Rights Commission, Tom Calma, who took the running on this issue. As a five-year statutory appointee chosen by the Howard government in late 2004, Calma had a useful degree of independence from the Rudd government. In July, he released a research paper that discussed past Australian and overseas experience of Indigenous representative bodies and identified issues for discussion (ATSISJC 2008a). Calma then started addressing conferences and seminars identifying six foundational principles for a new national Indigenous representative body: legitimacy and credibility with both governments and Indigenous people, 
two-way accountability, transparency, representation of the diverse range of Indigenous peoples, links to Indigenous bodies at state/territory and regional levels and independent and robust advocacy and analysis (ATSISJC 2008b).

In December 2008, the Rudd government asked Calma to convene an independent steering committee to progress the representative body issue. In March 2009, Calma and the steering committee organised a threeday workshop of 50 Indigenous men and 50 Indigenous women from 'all age groups' and geographic areas, selected from 263 applicants, to 'lay the groundwork for a new national Indigenous representative body' (AHRC 2009a). Minister Macklin addressed the workshop and asked for its 'advice about the best way forward', while also anticipating that there would be 'a great diversity of views about the role of the new national representative body and who should be on it' (Macklin 2009b). Macklin hoped, however, that Calma and the steering committee would report to her by July and that the new body might be established by the end of 2009 .

The March 2009 workshop actually identified considerable common ground among Indigenous people on a national representative body. There was a push for equal representation of women and men, led by former ATSIC chairwoman Lowitja O'Donoghue. There was agreement that the new body should not deliver programs and services, but rather should have a strong advocacy and monitoring role. It was also agreed that members of the new body should not be appointed by government, but rather should be selected on the basis of merit by Aboriginal and Torres Strait Islander people - though whether by election or delegation was still to be worked out. Also there was agreement that the national body needed to build up from local and regional levels to ensure the representation of the diversity of Aboriginal and Torres Strait Islander communities. One final point of agreement was rejection of the term 'Indigenous' in the body's name in favour of either 'First Nations' or 'First Peoples' (AHRC 2009b).

Calma and the steering committee disseminated a model for the new national Indigenous representative body in August 2009. It comprised a National Congress of 128 members, eight of whom would form a National Executive, with the other 120 drawn from three different 40-member chambers: a National Peak Bodies Chamber, a Sectoral Peak Bodies Chamber and an individual Merit Selection Chamber. The national body would also have an Ethics Council, to conduct the merit selection process and to develop and maintain ethical standards. Further, it would be a company limited by guarantee, rather than a statutory authority, in order to be more independent of Parliament and to attract 'corporate and philanthropic support', though it was also suggested that the government should fund the establishment phase and the first five years of operation. The approach being adopted 
was described as developmental and the tasks listed in August 2009 for achievement by the end of 2010 were to establish a company and office and to convene the first National Congress (AHRC 2009c).

On 22 November 2009, Minister Macklin announced that the Rudd government supported this model and would fund the establishment of the new representative body with $\$ 6$ million (Macklin 2009c). The new body was to be called the National Congress of Australia's First Peoples and, on 2 May 2010, the inaugural, full-time male and female co-chairs of the company were announced as Sam Jeffries and Kerry Arabena, along with six other directors (AHRC 2010a). Calma was, by then, no longer the Aboriginal and Torres Strait Islander Social Justice Commissioner, but his successor, Mick Gooda, remained heavily involved in the inauguration of the new representative body (AHRC 2010b). ${ }^{3}$ More than five years since the abolition of ATSIC, Australia now had the beginnings of a new national Indigenous representative body, supported, but not quite so directly created, by the Commonwealth Parliament and government. The Rudd government could claim to have delivered on a longstanding Labor commitment.

\section{Declaration on the Rights of Indigenous Peoples}

One other event during the last days of the Howard government to which Rudd needed to respond was the passing of the Declaration on the Rights of Indigenous Peoples by the UN General Assembly on 13 September 2007. This declaration had been more than 20 years in the making and there were times when Australia was a strong supporter of it. In the last years of its development, however, and in the final vote in the General Assembly, Australia and three other British-majority settler countries-Canada, New Zealand and the United States - were the only four countries that opposed the declaration. This ensured that the Rudd government would come under considerable pressure to change Australia's stance.

Tom Calma had already been critical of the reasoning behind the Howard government's impending opposition to the declaration in his 2006 Social Justice Report and it was to him, again, that the Rudd government turned in 2008 for counsel on how to change course. Between April and August 2008, Calma sought and received 'a great deal of feedback' on the declaration

3 Calma became an inaugural member of the Ethics Council of the new representative body in January 2010 - about the time he was finishing his term as Aboriginal and Torres Strait Islander Social Justice Commissioner within the Australian Human Rights Commission. 
from Indigenous organisations and individuals (AHRC 2008). Others too were expressing strong views to the Rudd government during 2008 about changing Australia's stance (HRLRC and ILC 2008). After some criticism for not acting earlier, the Rudd government indicated in March 2009 that it would be making a statement belatedly giving Australia's support to the declaration.

Minister Macklin's speech at Parliament House in Canberra on 3 April 2009 described Australia's change of position to 'support' the declaration as 'another important step in re-setting the relationship between Indigenous and non-Indigenous Australians' (Macklin 2009d:1). She emphasised that under Article 1 of the declaration, Indigenous peoples 'as a collective or as individuals' enjoy 'all human rights and fundamental freedoms as recognised in international law'. She also noted 'with solemn reflection on our history and the failed policies of the past' that Article 8 indicated the right of Indigenous peoples 'not to be subject to forced assimilation or destruction of their culture' and that Article 10 said they were 'not to be forcibly removed from their lands or territories' (Macklin 2009d:2). Macklin emphasised that the declaration needed to be considered in its totality and that the right to self-determination of Indigenous peoples in Article 3 should be read in conjunction with Article 46, which stated that nothing in the declaration should impair the 'territorial integrity or political unity' of states such as Australia (Macklin 2009d:3). She also noted Article 7, identifying the right of Indigenous peoples 'to lives that are safe, secure and free from intimidation and violence', and Article 22, focusing on the rights of Indigenous 'elders, women, youth, children and people with disability'. Macklin saw these groups as 'vulnerable people' who needed particular attention and who also drew rights from more longstanding UN conventions (Macklin 2009d:4). Macklin was, quite explicitly here, defending the Rudd government's support for aspects of the NTER that were, at the time, the subject of a complaint before the UN Committee on the Elimination of Racial Discrimination and were, more generally, subject to strong criticism (Nicholson et al. 2009). Macklin noted and welcomed an impending visit of the UN Special Rapporteur for Indigenous Peoples, James Anaya, who would examine the NTER and other matters, and she also reiterated the Rudd government's intention to pass legislation that would 'lift the suspension of the Racial Discrimination Act in the Northern Territory' (Macklin 2009d:3-4). The minister was clearly keen to rebut any idea of inconsistency between the Rudd government's support for the Declaration on the Rights of Indigenous Peoples and what it was doing in the Northern Territory. The NTER was, as she saw it, pursuing Indigenous rights, even if it required some reform in how it was doing so. ${ }^{4}$

4 Anaya's report in February 2010 was of the view that the NTER, as then constituted, was contrary to the declaration and other human rights instruments (Anaya 2010). 


\section{Multilateral intergovernmental agreement making}

One final aspect of the Rudd government's approach to Indigenous affairs, which emerged during its term rather than being clear at the outset, was development in multilateral intergovernmental agreement making. Rudd's proposed bipartisan 'joint policy commission' struggled to become a reality in the year after his apology address in February 2008, and perhaps multilateral intergovernmental agreement making emerged as an alternative way to project an image of national unity and concerted commitment in Indigenous affairs.

After a Council of Australian Governments (COAG) meeting in November 2008, it was announced that state and territory governments were joining with the Commonwealth in major reforms of their financial relations. A new Intergovernmental Agreement on Federal Financial Relations was being finalised, which would reduce 90 previous Specific Purpose Payments from the Commonwealth to the states and territories to just five (COAG 2008a). These five national agreements, with dollars attached, would be in the areas of health care, education, skills and workforce development, disability services and affordable housing. But there would also be a sixth, crosscutting intergovernmental agreement called the National Indigenous Reform Agreement. This sixth agreement focused on six 'close-the-gap' targets that had already been agreed to at other COAG meetings earlier in the year and it aimed to articulate a framework for achieving these targets (COAG 2008b). Although this agreement would not itself have dollars attached, it identified subsidiary Indigenous-specific national partnership agreements that would. Five of these were already identified and more were anticipated. One such national partnership agreement, signed in December 2008, focused on remote Indigenous housing and identified almost $\$ 5$ billion that would be available to the states and territories over the next 10 years (COAG 2008c). Another, focusing on remote service delivery, adopted a more modest approach in identifying \$188 million of commonwealth money to be combined with \$104 million of state and territory funding over just a one-year period. The latter also identified that 'initial investment' would be concentrated in 26 remote locations: 15 in the Northern Territory, four in Queensland, three in Western Australia, two in South Australia and two in New South Wales (COAG 2008d).

Multilateral intergovernmental agreement making is not entirely new in Australian Indigenous affairs. In 1992, in the flurry of collaborative federalism initiated by the late Hawke and early Keating governments, a general multilateral agreement had been signed: the National Commitmentto Improved Outcomes in the Delivery of Programs and Services for Aboriginal Peoples and Torres Strait Islanders (COAG 1992). Since that time, however, 
intergovernmental agreements in Indigenous affairs had been bilateralbetween the Commonwealth and particular states and territories-rather than multilateral. The return to multilateralism, involving quite specific expenditure figures and conditions, marked an interesting development in Indigenous affairs in which the Commonwealth was possibly becoming more directive and even possibly setting up competition between the states and territories. The latter seemed to be demonstrated at the end of 2009 in the remote Indigenous housing partnership, when some states and territories were having trouble delivering results. After a COAG meeting one year on from the original signing, the Prime Minister announced that the National Partnership Agreement on Remote Indigenous Housing was undergoing 'renegotiation' to 'enable a more competitive process for allocation of funding by the Commonwealth' from financial year 2010-11 (Rudd 2009). In July 2010, Macklin announced that Western Australia had 'demonstrated its capacity to deliver additional capital works' and would receive an extra $\$ 4$ million in 2010-11, while Queensland and South Australia would together be penalised this amount (Macklin 2010c). Multilateral agreement making was thus also turning into a form of competitive, centralised funding allocation and direction.

Another interesting aspect of this multilateralism was the appointment by the Rudd government in 2009 of a Coordinator-General for Remote Indigenous Services. This statutory officer would 'drive the implementation of major reforms in housing, infrastructure and employment in remote Indigenous communities' and 'report directly to the Minister for Indigenous Affairs'. Along with a requirement for a formal report twice a year to 'provide information to Commonwealth, state and territory agencies on obstacles within their areas of responsibility and advise the Minister for Indigenous Affairs and COAG on the need for any necessary changes', the CoordinatorGeneral would be 'given the authority to coordinate across agencies, to cut through bureaucratic blockages and red tape, and to make sure services are delivered effectively' (Macklin 2009e). If this public management language is to be believed, Indigenous affairs was about to be transformed. Multilateral agreement making and the Coordinator-General were going to form the panacea and, unlike all the failed policies before them, would finally find the magic formula for Australian Indigenous affairs. But perhaps, like so much else in Indigenous affairs, there was more aspiration and moral indignation in this managerial language than strategy or capacity. 


\section{Evidence, competing principles and generational revolutions}

The Rudd government's preferred frame for Indigenous affairs is the idea of an evidenced-based approach, which is said to transcend ideology. One of us has already critiqued this frame as an analytical approach and suggested instead the idea of three competing principles in Indigenous affairs: equality, choice and guardianship (Sanders 2009). Figure 12.1 arranges these principles in a triangular policy space. It also allows for three different interpretations of the equality principle and for relating the choice and guardianship principles to positive and negative views of Indigenous difference and diversity. These competing principles and their alternative interpretations make Indigenous affairs a complex policy arena, which can be drawn in quite different directions over time, through generational revolutions and the rebalancing principles.

Figure 12.2 suggests how dominant debates in Australian Indigenous affairs have moved since the 1930s. The generational revolution of the late 1960s and early 1970s reflected a move away from the principles of legal equality and guardianship on the right of this analytical schema towards the principles of socioeconomic equality and choice on the left. The more recent generational revolution in Indigenous affairs since the year 2000 would seem, at one level, to be a move back to the right towards the principle of guardianship. At another level, however, Indigenous affairs is, at all times, balancing the three interpretations of the equality principle and the choice and guardianship principles. Noel Pearson suggests that the 'quest' is for a 'radical centre' in Australian Indigenous policy in which 'policy positions' are 'much closer and more carefully calibrated than most people imagine'. He also suggests that this will involve continuing 'dialectical tension' between 'opposing principles', rather than a clear resolution of policy in favour of any one principle (Pearson 2007). This schema and Pearson's idea of the radical centre do not see evidence as either so significant or neutral as in the Rudd Labor perspective. Evidence always needs to be interpreted and contextualised and, in so being, is inevitably drawn into the balancing of competing principles. Good Indigenous affairs public policy - if Australia is ever to achieve it will be based on a self-conscious awareness of competing principles and of the tendency towards generational revolutions in this difficult cross-cultural and highly morally charged policy arena. Simple notions of evidence-based policy are inadequate as a central idea for either understanding or judging Australian Indigenous affairs. 


\section{Socio-economic - Opportunity - Legal}

Choice

$$
\text { Equality }
$$

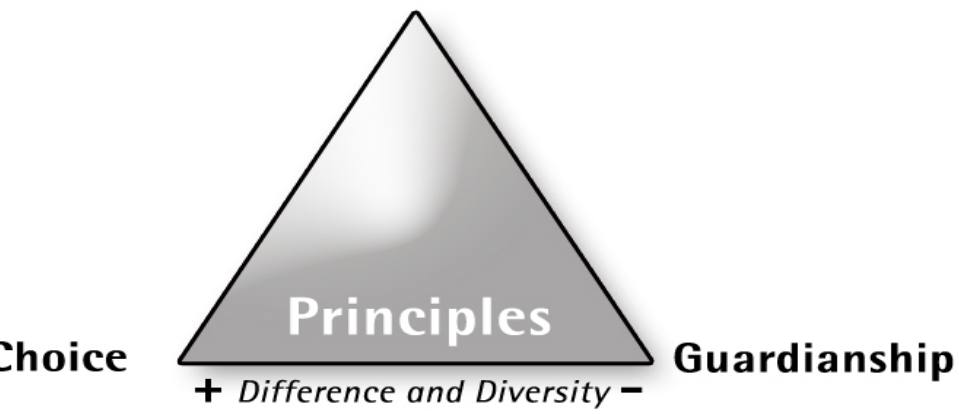

Figure 12.1 Competing principles in Indigenous affairs

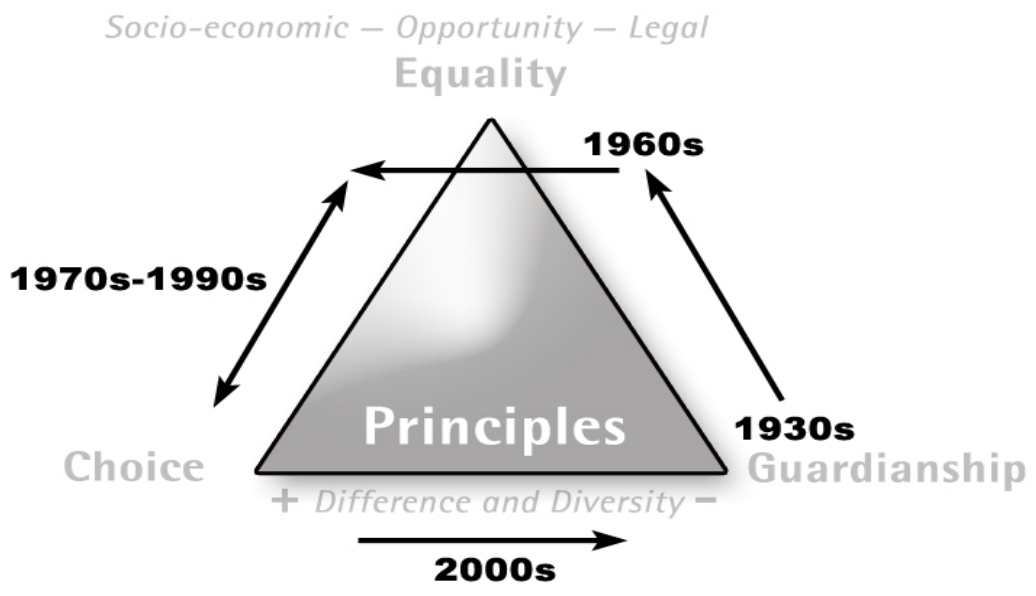

Dominant Debates

Figure 12.2 Dominant debates in Indigenous affairs 
Will Sanders is Senior Fellow and Deputy Director at the Centre for Aboriginal Economic Policy Research, Research School of Social Science, The Australian National University.

Janet Hunt is a Fellow in the Centre for Aboriginal Economic Policy Research, Research School of Social Sciences, The Australian National University.

\section{References}

Aboriginal and Torres Strait Islander Social Justice Commissioner (ATSISJC) 2008a. Building a Sustainable National Indigenous Representative BodyIssues for consideration, Human Rights and Equal Opportunity Commission, Sydney.

Aboriginal and Torres Strait Islander Social Justice Commissioner (ATSISJC) 2008b. Speech for the Australian Institute of Aboriginal and Torres Strait Islander Studies Seminar Series, 4 August.

Altman, J. 2009. Beyond closing the gap: valuing diversity in Indigenous Australia, Working Paper 54, Centre for Aboriginal Economic Policy Research, The Australian National University, Canberra.

Anaya, J. 2010. Observations on the Northern Territory Emergency Response in Australia, Advance version, February, United Nations Special Rapporteur on Indigenous People, Office of the United Nations High Commissioner for Human Rights, Geneva, <http://www.hrlrc.org.au/files/Special-RapporteurReport-NTER.pdf>

Australian Government 2009a. Landmark reform to the welfare system, reinstatement of the Racial Discrimination Act and strengthening of the Northern Territory Emergency Response, Policy statement, Commonwealth of Australia, Canberra.

Australian Government 2009b. Future directions for the Northern Territory Emergency Response, Discussion Paper, 21 May, Commonwealth of Australia, Canberra.

Australian Government 2009c. Report on the Northern Territory Emergency Response Redesign Consultations, Commonwealth of Australia, Canberra.

Australian Human Rights Commission (AHRC) 2008. Australia's Support for the Declaration on the Rights of Indigenous Peoples, Australian Human Rights Commission, Sydney, <http://www.hreoc.gov.au/social_justice/declaration/ comments.html> 
Australian Human Rights Commission (AHRC) 2009a. National Indigenous workshop kicks off in Adelaide next week, Media release, 6 March, Australian Human Rights Commission, Sydney.

Australian Human Rights Commission (AHRC) 2009b. Getting it RightProgress towards a new national representative body: a community guide, May, Australian Human Rights Commission, Sydney.

Australian Human Rights Commission (AHRC) 2009c. Our Future in Our HandsCreating a sustainable national Indigenous representative body: a community guide, August, Australian Human Rights Commission, Sydney.

Australian Human Rights Commission (AHRC) 2010a. New congress to represent Aboriginal and Torres Strait Islanders, Media release, 2 May, Australian Human Rights Commission, Sydney.

Australian Human Rights Commission (AHRC) 2010b. First national executive is a milestone moment for Indigenous Australians, Media release, 2 May, Australian Human Rights Commission, Sydney.

Council of Australian Governments (COAG) 1992. National Commitment to Improved Outcomes in the Delivery of Programs and Services for Aboriginal Peoples and Torres Strait Islanders, Endorsed 7 December, Council of Australian Governments, Perth.

Council of Australian Governments (COAG) 2008a. Communiqué, 29 November, Council of Australian Governments, Canberra.

Council of Australian Governments (COAG) 2008b. National Indigenous Reform Agreement, November, Council of Australian Governments, Canberra.

Council of Australian Governments (COAG) 2008c. National Partnership Agreement on Remote Indigenous Housing, December, Council of Australian Governments, Canberra.

Council of Australian Governments (COAG) 2008d. National Partnership Agreement on Remote Service Delivery, December, Council of Australian Governments, Canberra.

Grattan, M. and Wright, T. 2008. 'Rudd rules out compensation', The Age, 2 February.

Human Rights Law Resource Centre and Indigenous Law Centre (HRLRC and ILC) 2008. UN Declaration on the Rights of Indigenous Peoples, Letter to the Hon. Kevin Rudd MP, Prime Minister, 16 May, Human Rights Law Resource Centre and Indigenous Law Centre. 
Hunt, J. 2008. Failure, evidence and new ideas, Topical Issue Paper No. 1, Centre for Aboriginal Economic Policy Research, The Australian National University, Canberra.

Lennon, P. 2008. 'Cash is a mere gesture', The Australian, 29 January.

Macklin, J. 2008a. Closing the gap-building an Indigenous future, Address to the National Press Club, Canberra, 27 February.

Macklin, J. 2008b. Macklin meets Northern Territory Emergency Taskforce, Media release, 17 January, Parliament House, Canberra.

Macklin, J. 2008c. Permit system on Aboriginal land in NT, Media release, 17 February, Parliament House, Canberra.

Macklin, J. 2008d. NT Emergency Response Review Board, Media release, 6 June, Parliament House, Canberra.

Macklin, J. 2008e. Northern Territory Emergency Response-one year on, Media release, 20 June, Parliament House, Canberra.

Macklin, J. 2008f. Compulsory income management to continue as key NTER measure, Media release, 23 October, Parliament House, Canberra.

Macklin, J. 2008g. National Indigenous Council, Media release, 15 January, Parliament House, Canberra.

Macklin, J. 2009a. Strengthening the Northern Territory Emergency Response, Media release, 25 November, Parliament House, Canberra.

Macklin, J. 2009b. Speech, National Indigenous Representative Body Workshop, 11 March.

Macklin, J. 2009c. Australian Government response to 'Our Future in Our Hands', Media release, 22 November, Parliament House, Canberra.

Macklin, J. 2009d. Statement on the United Nations Declaration on the Rights of Indigenous Peoples, Speech, Parliament House, Canberra, 3 April.

Macklin, J. 2009e. Office of Coordinator-General of Remote Indigenous Services, Media release, 27 May, Parliament House, Canberra.

Macklin, J. 2010a. Major welfare reforms to support vulnerable Australians, Media release, 22 June, Parliament House, Canberra.

Macklin, J. 2010b. Racial Discrimination Act to be restored in the Northern Territory, Media release, 22 June, Parliament House, Canberra. 
Macklin, J. 2010c. Remote Indigenous housing progress, Media release, 15 July, Parliament House, Canberra.

Nicholson, A., Behrendt, L., Vivian, A., Watson, N. and Harris, M. 2009. Will They Be Heard? - A response to the NTER consultations June to August 2009, Jumbunna Indigenous House of Learning, University of Technology, Sydney.

Parliament of Australia 2008. House of Representatives, Debates, 13 February, Parliament of Australia, Canberra.

Pearson, N. 2007. 'White guilt, victimhood and the quest for a radical centre', Griffith Review, vol. 16, pp. 13-58.

Rudd, K. 2009. Renegotiation of the National Partnership Agreement on Remote Indigenous Housing, Media release, 7 December, Brisbane.

Sanders, W. 2005. 'Never even adequate: Indigenous affairs and reconciliation', in C. Aulich and R. Wettenhall (eds), Howard's Second and Third Governments: Australian Commonwealth Administration 1998-2004, UNSW Press, Sydney.

Sanders, W. 2008. 'In the name of failure: a generational revolution in Indigenous affairs', in C. Aulich and R. Wettenhall (eds), Howard's Fourth Government: Australian Commonwealth Administration 2004-2007, UNSW Press, Sydney.

Sanders, W. 2009. Ideology, evidence and competing principles: from Brough to Rudd via Pearson and the NTER, Discussion Paper 289, Centre for Aboriginal Economic Policy Research, The Australian National University, Canberra.

Yu, P., Ella Duncan, M. and Gray, B. 2008. Northern Territory Emergency Response: Report of the NTER Review Board, October, Commonwealth of Australia, Canberra. 